\title{
A ANÁLISE TEXTUAL DISCURSIVA COMO UMA BÚSSOLA PRAXIOLÓGICA À PERSPECTIVA FREIREANA DE EDUCAÇÃO
}

\author{
THE DISCURSIVE TEXTUAL ANALYSIS AS A PRAXEOLOGICAL \\ COMPASS IN THE FREIREAN PERSPECTIVE OF EDUCATION
}

\author{
Júlio César Lemos Milli ${ }^{1}$ \\ Ana Paula Solino ${ }^{2}$ \\ Simoni Tormöhlen Gehlen ${ }^{3}$
}

\begin{abstract}
Resumo: Alguns estudos têm discutido contribuições da Análise Textual Discursiva (ATD) no desenvolvimento de pesquisas baseadas na perspectiva freireana. Todavia, há de se evidenciar aspectos teórico-metodológicos da ATD que se aproximam da abordagem freireana, tendo em vista as articulações já realizadas com a Investigação Temática. Assim, busca-se investigar aproximações e complementaridades da realização da ATD na Investigação Temática - processo de obtenção de Temas Geradores -, tomando como ponto de partida os pressupostos freireanos de educação e a análise do Projeto Inter, desenvolvido durante o Movimento de Reorientação Curricular de São Paulo. As diferentes releituras da Investigação Temática e suas relações com a ATD permitiram caracterizar os potenciais metodológico, hermenêutico e dialético. Esses potenciais se expressam sobre a abertura da ATD à realização da práxis, fato que justifica sua utilização nos trabalhos de cunho freireano, bem como a configura como uma bússola praxiológica, que pode orientar/operacionalizar a busca pela transformação da realidade.
\end{abstract}

Palavras-chave: Paulo Freire; Investigação Temática; Metodologia de Análise.

Abstract: Some studies have discussed contributions that the Discursive Textual Analysis (DTA) has given to the development of research based on the Freirean perspective. However, theoretical and methodological aspects of the DTA, which are close to Freire's approach, must be highlighted, considering previous articulations with Thematic Research. Thus, this study aims to investigate approximations and complementarities of the DTA in Thematic Investigation - the process that leads to Generating Themes -, taking as a starting point the Freirean assumptions of education and the analysis of the Inter Project, developed during the São Paulo Curriculum Reorientation Movement. Different reinterpretations of Thematic Research and their relations with the DTA enabled to characterize its methodological, hermeneutic and dialectical potential, which is expressed as the openness of the DTA towards praxis, a fact that justifies its use in studies based on Freire. It also configures it as a praxeological compass, which can guide/operationalize the search for transformation of reality.

Keywords: Paulo Freire; Thematic Research; Analysis Methodology.

\footnotetext{
${ }^{1}$ Mestre em Educação em Ciências - PPGEC/UESC. Doutorando no PPGECT/UFSC, Florianópolis, SC, Brasil. E-mail: juliocesarmilli@gmail.com

${ }^{2}$ Doutora em Educação - FEUSP/USP. Docente do Curso de Pedagogia da UFAL/Campus do Sertão, Delmiro Gouveia, AL, Brasil. E-mail: ana.solino@gmail.com

${ }^{3}$ Doutora em Educação Científica e Tecnológica - PPGECT/UFSC. Docente do DCET-PPGECM/UESC, Ilhéus, BA, Brasil. E-mail: stgehlen@uesc.br
} 


\section{Introdução}

O educador pernambucano Paulo Freire (1921-1997) foi reconhecido inicialmente pela sua proposta de alfabetização de Jovens e Adultos em um processo educativo realizado na cidade de Angicos, Rio Grande do Norte, onde alfabetizou 300 trabalhadores durante 45 dias (A. M. SAUL; SILVA, 2009; FREIRE ${ }^{4}$, 1979). Desde então, seu trabalho se estendeu por diversas capitais do Brasil, em busca de uma pedagogia da liberdade, voltada para a emancipação dos sujeitos frente ao seu estado de opressão e pautada na superação da realidade social, política e econômica desses sujeitos (WATANABE, 2019; DELIZOICOV, N.; STUANI; CUNHA, 2018; PORTO; LIMA, 2016, SAUL, 2016; SAUL; SILVA, 2009; SILVA, 2004; DELIZOICOV, 2008; FREIRE, 1979, 1987). A. M. Saul (2016) sinaliza que o educador Paulo Freire também é referência no mundo ${ }^{5}$ por seus trabalhos, sendo destaque entre os educadores do século $\mathrm{XX}$, de modo que o seu pensamento permanece vivo $\mathrm{e}$ atual diante das necessidades educativas da contemporaneidade.

No processo de alfabetização e pós-alfabetização de adultos, Paulo Freire (1987; 1967) apresenta alguns dos seus indicadores teóricos e metodológicos que orientam as práticas educativas em favor da libertação dos seres humanos (NERES; GEHLEN, 2018). No âmbito da alfabetização, Neres e Gehlen (2018) caracterizam na obra do autor o processo de obtenção das Palavras Geradoras e na pós-alfabetização sinalizam a Investigação Temática, a qual consiste em uma adaptação da obtenção das Palavras Geradoras que se deu para responder às necessidades do contexto da pós-alfabetização. A Investigação Temática, por sua vez, foi desenvolvida por Freire (1987) como um processo capaz de localizar as visões de mundo dos sujeitos caracterizadas por situaçõeslimites - as quais impedem que os mesmos se emancipem -, e seus Temas Geradores, bem como reconhecer e organizar no âmbito político e pedagógico os conhecimentos necessários à superação e transformação da realidade.

A sistematização da Investigação Temática para a educação escolar ocorreu durante o desenvolvimento do projeto Formação de professores de Ciências Naturais, realizado na Guiné-Bissau, África, entre os anos de 1979 e 1981, sendo coordenado pelos respectivos professores Demétrio Delizoicov e José Angotti, na $5^{\mathrm{a}}$ e $6^{\mathrm{a}}$ série do Ensino

\footnotetext{
${ }^{4}$ Nesta obra, Freire faz referência a outros estudos para discutir e apresentar as informações históricas e projeções de sua pedagogia, a exemplo do trabalho de Francisco C.Weffort.
} 
Fundamental de Ciências Naturais (DELIZOICOV, 2008; DELIZOICOV, 1991). Com a sistematização da Investigação Temática (DELIZOICOV, 1982, 1991), Muenchen e Delizoicov (2012) ressaltam o desenvolvimento de um "roteiro pedagógico" " que permite a organização do trabalho escolar em três momentos distintos, quais sejam: Estudo da Realidade, Estudo Científico e Trabalho Prático, dos quais se originaram os Três Momentos Pedagógicos (MUENCHEN; DELIZOICOV, 2012). Esses momentos foram utilizados na organização do currículo do município de São Paulo conhecido, desde então, como Movimento de Reorientação Curricular, durante a realização do projeto Interdisciplinaridade via Tema Gerador, no decorrer dos anos de 1989 até 1992 (MUENCHEN; DELIZOICOV, 2012; MUENCHEN, 2010). Desde esse período, o processo de Investigação Temática tem passado por diversas reconfigurações e adaptações, tendo em vista o desenvolvimento de uma pedagogia libertadora (DELIZOICOV; DELIZOICOV, N.; SILVA, 2020; NERES, 2016; SILVA, 2004; DELIZOICOV, 2008; BRASIL, 1994; PONTUSCHKA, 1993).

Embora esse Movimento de Reorientação Curricular baseado na pedagogia freireana tenha utilizado a metodologia da Análise de Prosa (ANDRÉ, 1983) para auxiliar no processo de investigação dos Temas Geradores nas escolas municipais de São Paulo, atualmente, no contexto da Educação em Ciências, algumas pesquisas têm buscado desenvolver articulações teórico-metodológicas de releituras do processo de Investigação Temática de Paulo Freire (NERES, 2016). Dentre os quais, destacam-se aqueles com base na metodologia da Análise Textual Discursiva, proposta por Moraes e Galiazzi (2011), a exemplo de Milli, Solino e Gehlen (2018), Silva et al., (2017), Milli et al., (2016), Oliveira e Recena (2009) e Torres et al., (2008). Além disso, Gonçalves (2020) endossa e situa a relevância de trabalhos, como de Torres et al., (2008), ressaltando a necessidade de evitar a utilização da ATD em pesquisas de caráter analítico relativista, as quais colocam em posições hierárquicas semelhantes os conhecimentos do senso comum e os conhecimentos científicos. O autor defende a necessidade de prezar por uma coerência de referenciais teóricos com o método da ATD, a exemplo dos estudos freireanos que têm utilizado tal ferramenta como procedimento analítico das informações.

Em vista disso, uma busca no Google Acadêmico pelas palavras “Análise Textual Discursiva" associada a "Paulo Freire" identificou mais de 1.700 resultados e, a "Análise

\footnotetext{
${ }^{6}$ Muenchen e Delizoicov (2012, p. 204) revelam que "esse roteiro já era utilizado pelo Centro de Educação Popular Integrada (CEPI), coordenado pelo Institut de Recherché, Formation e Developpement (IRFED) em parceria com o Ministério da Educação da Guiné Bissau".
} 
Textual Discursiva" associada a "Investigação Temática" apresentou cerca de 300 resultados ${ }^{7}$. Embora não se tenha realizado uma análise sistemática desses trabalhos, essa consulta corrobora a ideia de que a ferramenta da Análise Textual Discursiva esteja sendo associada de alguma forma com os pressupostos freireanos, seja para discussão e análise de informações ou até mesmo para o encaminhamento da Investigação Temática.

Contudo, conforme já mencionado, a Análise de Prosa foi uma das ferramentas analíticas utilizadas para suprir as necessidades teórico-metodológicas de um dos mais amplos processos de Investigação Temática já realizados no Brasil, no início da década de 1990 (NERES, 2016; DELIZOICOV, 2008). No entanto, três décadas após a realização desse processo, a Análise Textual Discursiva tem se consolidado como uma ferramenta que vem sendo utilizada na realização da Investigação Temática ou associada às pesquisas freireanas (GONÇALVES, 2020). Nesse sentido, busca-se indagar sobre as seguintes questões: Sob qual ponto de vista teórico-metodológico, poderia justificar a utilização da Análise Textual Discursiva nos estudos freireanos e na Investigação Temática? Não seria a Análise de Prosa uma metodologia suficiente para cumprir os objetivos da perspectiva freireana? Assim, este trabalho investiga aproximações e complementaridades da realização da Análise Textual Discursiva na Investigação Temática tendo como ponto de partida os pressupostos freireanos de educação e a análise do projeto Interdisciplinaridade via Tema Gerador, no âmbito do Movimento de Reorientação Curricular, realizado na cidade de São Paulo.

\section{A sistematização da Investigação Temática e o Movimento de Reorientação Curricular: (re)visitando caminhos}

A Investigação Temática, de acordo com Freire (1987), pode ser concebida como um processo vivo de busca pelos Temas Geradores, assim como também pode ser vista como um processo de construção coletiva de entendimentos e saberes envolvidos nos problemas vivenciados pelos sujeitos. A sua constituição decorre da investigação da Palavra Geradora, estratégia elaborada por Freire para alfabetizar jovens e adultos, a partir de palavras que possuam um sentido e significado efetivo à realidade concreta dos sujeitos, tendo por base o reconhecimento do seu "universo vocabular" (NERES; GEHLEN, 2018).

\footnotetext{
7 Tal metodologia de busca no Google Acadêmico sobre a Análise Textual Discursiva foi inspirada na pesquisa de Sousa, Galiazzi e Schmidt (2016).
} 
A obra Pedagogia do Oprimido pode ser considerada principal fonte em que Freire (1987) aborda, mais especificamente no Capítulo 3, o processo metodológico para investigar os Temas Geradores. A Investigação Temática foi estruturada em quatro fases que envolvem desde a identificação das visões de mundo dos sujeitos, suas interpretações e as contradições da realidade, até a seleção de temáticas significativas e a organização da programação do trabalho pedagógico a ser devolvido ao povo.

Tendo em vista as possibilidades de implementar a pedagogia freireana no contexto escolar, Delizoicov $(1982,1991)$ contribuiu ao sistematizar as etapas da Investigação Temática, delimitando as ações do investigador em cada momento. Ao sistematizá-las, este autor acrescentou a quinta etapa da Sala de Aula, uma vez que o seu enfoque estava direcionado aos processos ocorridos no âmbito escolar, diferente do contexto não formal de ensino, trabalhado por Paulo Freire. As etapas podem ser sintetizadas da seguinte forma: 1) Levantamento Preliminar: é realizado o reconhecimento da comunidade por meio de fontes secundárias de informação e conversas com os seus representantes; 2) Análise das situações e escolha das codificações: em um trabalho coletivo com uma equipe de investigadores é realizada uma análise das informações obtidas na primeira etapa a fim de escolher aquelas que representam as possíveis situações-limite vivenciadas pela comunidade, pelas quais os investigadores estabelecem "codificações" que representem essas contradições; 3) Diálogos descodificadores: as codificações são apresentadas por meio de diálogos com a comunidade e das situações-limite legitimadas com a comunidade se obtém os Temas Geradores; 4) Redução Temática: de forma interdisciplinar o conteúdo programático é selecionado para a compreensão do Tema Gerador e são planejadas as atividades escolares baseadas nos Três Momentos Pedagógicos e 5) Sala de Aula: as aulas elaboradas, juntamente com os conteúdos selecionados, são trabalhadas com os educandos.

Nesse contexto, a Investigação Temática tem se constituído num processo sujeito a reelaborações (DELIZOICOV, N.; STUANI; CUNHA, 2018; NERES; GEHLEN, 2018; NERES, 2016; MUENCHEN; DELIZOICOV, 2012; DELIZOICOV, 2008; BRASIL, 1994). O estudo de Delizoicov (2008) corrobora a ideia ao afirmar que o projeto Interdisciplinaridade via Tema Gerador - realizado via Investigação Temática, assumiu proporções desafiadoras, seja por aspectos operacionais - devido à amplitude do projeto - quanto aos conceituais - devido à proposta de articulação pedagógica e, que, por meio dessa iniciativa, diversos municípios do país passaram a implementar um currículo 
pautado na perspectiva freireana (DELIZOICOV, 2008). Saul e Silva (2009) também destacam nesse projeto a base da adoção da pedagogia libertadora de Paulo Freire de diversos Estados e municípios do Brasil.

Esse projeto, o Interdisciplinaridade via Tema Gerador, conhecido como Projeto Inter, que fez parte do Movimento de Reorientação Curricular (1989-1992), foi implementado durante o mandato da prefeita Luiza Erundina de Souza, sendo proposta da gestão do Secretário Municipal de Educação de São Paulo, Paulo Freire (1989-1991), o qual foi sucedido por Mário Sérgio Cortella (DELIZOICOV, DELIZOICOV, N.; SILVA， 2020; MUENCHEN; DELIZOICOV， 2012； SAUL； SILVA， 2011; MUENCHEN, 2010; BRASIL, 1994). Conforme o estudo realizado pelo Instituto Nacional de Estudos e Pesquisas Educacionais - INEP (BRASIL, 1994), no período de implantação do projeto, o município possuía aproximadamente 9,5 milhões de pessoas com uma extensão territorial de $1.509 \mathrm{~km}^{2}$. Nesse estudo também é destacada a diversidade cultural e geográfica do município, bem como os contrastes sociais presentes nas suas regiões, crescentes demandas da população (moradia, emprego, educação, etc.) e ambientais (BRASIL, 1994).

De acordo com o estudo do INEP (BRASIL, 1994, p. 28), o Projeto Inter foi aderido por diversas escolas do município de São Paulo, de modo que na "época, de 682 escolas havia 294 envolvidas em diferentes grupos de formação, 250 escolas em 130 projetos especiais e 91 escolas no Projeto Inter (Interdisciplinaridade via Tema Gerador)”. Esse projeto se destaca por buscar a reestruturação curricular pautada na realidade dos educandos, tendo em vista a sistematização e seleção dos conteúdos programáticos em torno dos Temas Geradores (BRASIL, 1994). O estudo do INEP (BRASIL, 1994) revelou que esse processo de reestruturação curricular exigiu o desenvolvimento de uma nova metodologia, instituída em um trabalho coletivo e integrado com educadores, educandos e comunidade, sendo estruturada em três etapas, a saber: 1) O estudo preliminar da localidade; 2) A escolha dos Temas Geradores e 3) A construção do programa. O Quadro 1 apresenta uma síntese dessas três etapas. 
Quadro 1: Processo de investigação e desenvolvimento do Tema Gerador no "Projeto Inter"

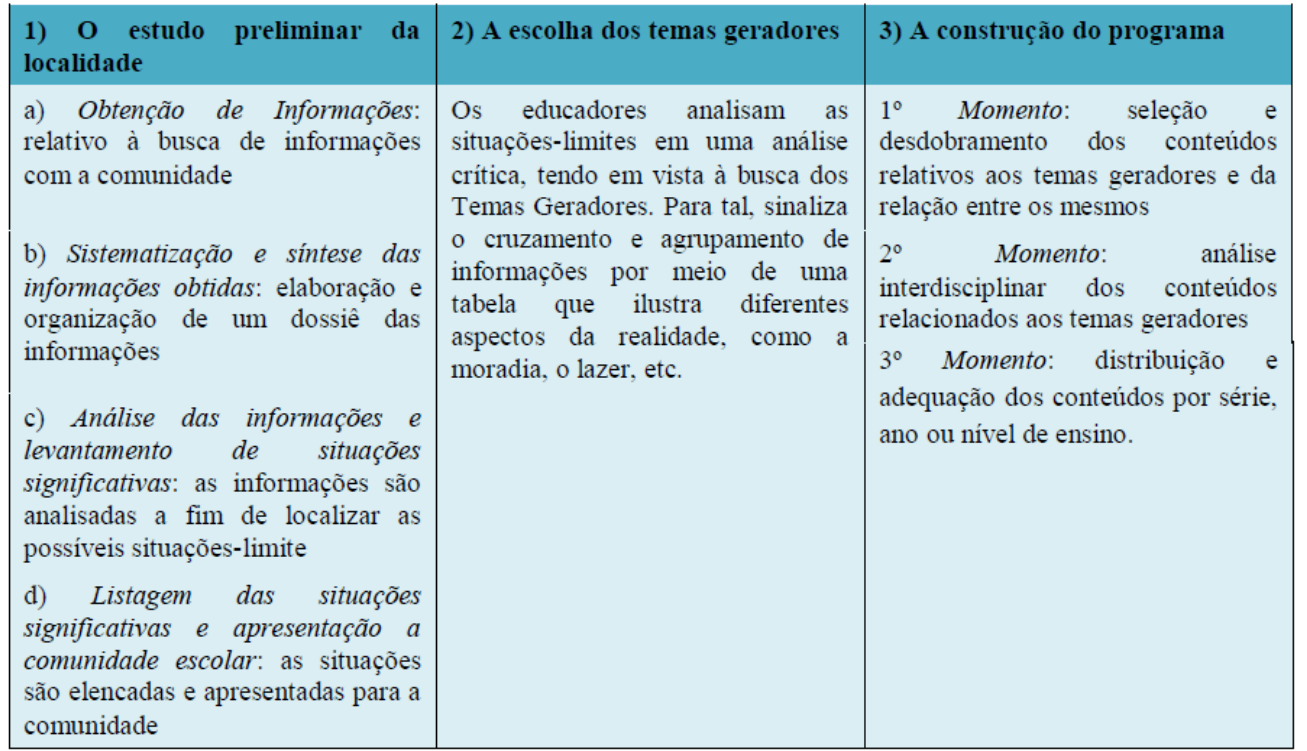

Fonte: Elaborado com base em informações do estudo do INEP (BRASIL, 1994) e do Caderno de Formação 01 e 02 (SÃO PAULO, 1990a, 1990b)

Tendo em vista os aspectos sinalizados no Quadro 1, o Caderno de Formação 02 (SÃO PAULO, 1990b) revela que a riqueza do material obtido com a comunidade expressa diferentes sentidos ao que se investiga, exigindo alguns indicadores analíticos para além do conteúdo manifesto. Sobre isso, destacam que:

\begin{abstract}
Para tanto, estamos propondo uma análise de conteúdo numa abordagem mais ampliada, como sugere Marli André (16): a análise de prosa. Segundo os autores citados por Marli E. A. A. de André, entende-se por análise de conteúdo, uma técnica de redução de um grande volume de material, num conjunto de categorias. Enquanto este tipo de análise fragmenta as informações, classifica-as em categorias, analisa-as de forma lógica, objetiva e sistemática, a análise de prosa extrapola essa visão mais restrita resgatando não só o conteúdo manifesto e suas contradições como o não manifesto através dos relatos de experiências, das falas espontâneas e intuitivas, das expressões faciais e artísticas, das mensagens não verbais e não implícitas (SÃO PAULO, 1990b, p. 43-44).
\end{abstract}

Neste Caderno de Formação 02 (SÃO PAULO, 1990b) é proposto o uso da metodologia da Análise de Conteúdo "ampliada", para tal referem-se aos pressupostos da Análise de Prosa do estudo de André (1983). Essa proposta ampliada se orienta pela busca do significado das informações analisadas, incluindo aspectos explícitos e não explícitos (ANDRÉ, 1983). Essa discussão presente neste documento se alinha a essa concepção ao revelar a existência de aspectos objetivos e subjetivos na realização de toda a análise, ressaltando que o sujeito que a realiza possui limitações, "preconceitos" e conhecimentos que lhes são intrínsecos, uma vez que "em qualquer situação e/ou problema analisado não

\footnotetext{
${ }^{8}$ Neres (2016) apresenta um quadro semelhante baseado no trabalho de Muenchen (2010).
} 
existe neutralidade, nem mesmo objetividade absoluta" (SÃO PAULO, 1990b, p.48). Neste sentido, ao fazer referência ao estudo de André (1983), reafirma-se a importância de se considerar na análise das informações obtidas durante a realização da Investigação Temática aspectos não manifestos à investigação (SÃO PAULO, 1990b). Esses aspectos, explícitos e não explícitos da Análise de Prosa (ANDRÉ, 1983), indicam possíveis articulações com a Análise Textual Discursiva proposta por Moraes e Galiazzi (2011).

\section{A Análise Textual Discursiva: uma compreensão ampliada da Análise de Prosa?}

Segundo André (1983), a Análise de Prosa emerge como alternativa à análise de informações de ordem qualitativa, constituindo uma releitura ampliada sobre o sentido atribuído ao termo da "Análise de Conteúdo". Isso porque a autora, pautada em trabalhos como os de Berelson (1952), George (1959), Holsti (1969) e Krippendorff (1980) ${ }^{9}$, tece algumas críticas sobre a compressão desses autores no uso da Análise de Conteúdo, tais como: a realização de uma análise estritamente objetiva; o uso de decomposições que levam a uma compreensão limitada e descontextualizada da realidade; o foco quantitativo e a negligência sobre os diferentes significados proporcionados pela análise, a quem ela ressalta o estudo de Krippendorff (1980), e o foco no conteúdo manifesto. Diante dessas lacunas, André (1983) destaca que a compreensão ampliada de uma Análise de Prosa pauta-se em elementos implícitos às informações, presentes em fotos, registros de vídeo, expressões corporais, dentre outros. Para tal, a autora considera que não seja estabelecido um sistema pré-fixado de categorias analíticas, mas que se elaborem tópicos e temas no desenvolvimento da análise, os quais estariam abertos a diferentes questionamentos e interpretações, balizados pelos princípios e pressupostos teóricos do estudo.

No desenvolvimento da compreensão ampliada sobre a Análise de Prosa, André (1983) também suscita alguns questionamentos que se impõe à realização dessa nova forma de análise, que se referem: ao método que seria mais indicado para a obtenção dos temas e tópicos; ao tipo de unidade analítica utilizada - fixa ou flexível; a relação do investigador com o seu objeto de análise; a forma de identificar aspectos implícitos e relevantes à análise - indo além do critério de frequência ${ }^{10}$; ao emprego da subjetividade e intuição na categorização e, a legitimidade ou "validade" da análise. Quanto a esse último aspecto, a autora sinaliza alguns fatores que necessitam ser considerados, quais

\footnotetext{
${ }^{9}$ Apud André (1983).

${ }^{10}$ A esse critério André (1983) faz referência a Guba e Lincoln (1981 apud ANDRÉ, 1983).
} 
sejam: i) A Credibilidade junto aos informantes ${ }^{11}$ - requer um processo de obtenção de informações que gere uma menor interferência dos informantes sobre o fenômeno investigado; ii) Corroboração por parte de outro (s) analista (a) - a realização de uma análise colaborativa com outros analistas e a iii) Triangulação de Informações - utilizar e combinar diversas técnicas de obtenção de informações. André (1983) também faz algumas considerações acerca da utilização da Análise de Prosa, sendo que:

\begin{abstract}
O processo de análise de prosa é algo que ainda precisa de muita elaboração. Se existe um método ou um sistema a ser criado, este deverá ter origem numa constante reflexão sobre a nossa prática de análise, à luz do contexto dos dados analisados e tendo em vista os pressupostos e concepções que orientam essa prática (ANDRÉ, 1983, p. 69).
\end{abstract}

Sendo assim, a Análise de Prosa encontra-se em desenvolvimento, o que demanda investigação. Porém, a autora discorre sobre três aspectos de sua prática que podem servir de aporte para o desenvolvimento dessa forma de análise "ampliada", sendo eles: 1) A análise perpassa todo o processo de investigação, de modo que é reconfigurada ao longo de um processo contínuo de "coleta e análise" de informações; 2) A análise necessita ser entendida como um processo coletivo, podendo envolver a discussão em grupo, seja durante toda a análise ou em momentos específicos, bem como a troca de materiais para análise no próprio grupo; 3) Desenvolver questões de pesquisa amplas, visando à apreensão do fenômeno em sua totalidade sem desconsiderar as suas particularidades, uma vez que "em última instância o que se procura obter num estudo é a compreensão ampla e profunda do objeto focalizado" (p. 70). Ao apresentar esses três aspectos, André (1983) também reitera a necessidade de continuidade dessa perspectiva de investigação, seja no encaminhamento dos sentidos expressos na análise das informações, na adoção de critérios analíticos ou na construção e legitimação das categorias de análise.

Diante das perspectivas de continuidade da concepção ampliada da Análise de Prosa (ANDRÉ, 1983), sinalizam-se alguns possíveis avanços promovidos pelo desenvolvimento da Análise Textual Discursiva de Moraes e Galiazzi (2011). A Análise Textual Discursiva busca a profundidade dos fenômenos investigados e se diferencia por seu vínculo com a perspectiva hermenêutica gadameriana, a qual considera o caráter ontológico da investigação, o contexto histórico e cultural, bem como a ampliação das pré-compreensões dos sujeitos no desenvolvimento da análise (SOUSA; GALIAZZI,

\footnotetext{
${ }^{11}$ A esse critério André (1983) faz referência a Guba e Lincoln (1981 apud ANDRÉ, 1983), Miles (1979
} apud ANDRÉ, 1983) e Stake (1980 apud ANDRÉ, 1983). 
2016; SOUSA; GALIAZZI; SCHMIDT, 2016; MORAES; GALIAZZI, 2011; MORAES, 2003).

De acordo com Moraes (2003), a Análise Textual Discursiva se estabelece em um ciclo orientado por quatro focos: Desmontagem dos textos, Estabelecimento de relações, Captando o novo emergente e Um processo auto-organizado. Esses quatro focos se complementam em três etapas recursivas, conforme o autor apresenta: 1) Unitarização: refere-se à seleção de unidades de sentido do material de estudo ou corpus textual, a qual ocorre por meio da desmontagem dos textos; 2) Categorização: busca estabelecer relações entre as unidades obtidas do corpus em categorias analíticas, seja por categorias definidas a priori, por um referencial teórico, e/ou durante a realização da análise; 3 ) Metatexto: constitui na expressão das novas compressões obtidas por meio da reorganização das unidades nas categorias, pautado no foco da captação do novo emergente. Para este autor, o desenvolvimento das três etapas consiste num processo auto-organizado, que possui relação direta com o envolvimento do investigador com a análise. Sousa, Galiazzi e Schmidt (2016) ressaltam que, embora as etapas da Análise Textual Discursiva se constituam num movimento cíclico, ela não se configura como um processo fechado e estático, pois se amplia e se reconfigura em razão das novas compreensões estabelecidas no desenvolvimento da análise.

Segundo Moraes e Galiazzi (2011), o processo de unitarização da Análise Textual Discursiva requer a desconstrução do corpus textual, o qual consiste no conjunto de informações utilizadas no desenvolvimento da análise. Os autores destacam que esse corpus pode ser elaborado por meio de diferentes metodologias, podendo reunir produções textuais bem como diferentes expressões linguísticas, as quais são atribuídas a uma diversidade de sentidos. De acordo com os autores, esse corpus é delimitado pelo critério de saturação, estabelecido à medida que "a introdução de novas informações na análise já não produz modificação nos resultados. Isso, naturalmente, implica um processo concomitante de coleta e análise" (MORAES; GALIAZZI, 2011, p. 17). Os autores consideram, ainda, que a partir do corpus textual o pesquisador busca por esses diferentes sentidos, sendo orientados pelos objetivos propostos pela pesquisa e pelo fenômeno investigado, aspectos que, segundo eles, possibilitam estabelecer as unidades de sentido e garantir a sua validade. Eles também ressaltam que esse processo não é neutro e defendem um "papel ativo do pesquisador" na busca por compreender e interpretar o fenômeno em estudo. Para isso, os autores orientam que na seleção de unidades seja realizada a adoção de critérios semânticos, na busca por "fundamentar a unitarização no 
significado" (MORAES; GALIAZZI, 2011, p. 59). Sousa e Galiazzi (2016) acentuam que o processo de estabelecimento de unidades de sentido se inicia antes mesmo de sua realização, tendo em vista as intencionalidades do investigador e os significados representados pelas unidades.

No encaminhamento do processo de análise, Moraes e Galiazzi (2011) destacam que a etapa de categorização opera sob a utilização e articulação de diferentes métodos, quais sejam: o dedutivo, o indutivo, o misto e o intuitivo. No método dedutivo, os autores discutem que as categorias analíticas são definidas a priori, a partir do referencial teórico, sendo elaboradas antes do desenvolvimento da análise das informações. Em contrapartida, os autores apresentam o método indutivo, no qual as categorias são criadas no desenvolver da análise, constituindo um processo de categorização emergente.

Uma terceira possibilidade referida pelos autores é a utilização de um método misto, que articula os métodos dedutivos e indutivos para a produção de categorias, de modo que o processo se inicia de teorias a priori e se afina com a construção de categorias emergentes. Por último, os autores revelam o método intuitivo, o qual trabalha com o "inesperado", resultado do envolvimento do pesquisador com o seu material de análise, que tem como referência a percepção da totalidade do fenômeno por meio de "insights" do pesquisador ao longo da investigação. Moraes e Galiazzi (2011) revelam que esses métodos são utilizados na seleção e organização de unidades, uma vez que nas categorias a priori as unidades são selecionadas com base nos referenciais que fundamentam essas categorias, já as categorias emergentes se formam da reorganização das unidades e dos sentidos estabelecidos ao longo da análise.

Moraes e Galiazzi (2011) entendem que o método dedutivo, intuitivo, e consequentemente o misto, envolve a intuição, considerada por eles como a responsável pela obtenção de novas compreensões sobre o fenômeno em estudo. Por essa razão, os autores salientam que dentre as análises textuais a Análise Textual Discursiva tem por princípios a busca em explicitar aspectos subjetivos da análise, especialmente quando se trabalha com a categorização emergente. Outro diferencial que pode ser ressaltado é a multiplicidades de sentidos com os quais essa forma de análise opera, permitindo que uma mesma unidade seja empregada em diferentes categorias de análise, a depender dos seus sentidos expressos (MORAES; GALIAZZI, 2011). Sousa e Galiazzi (2017) reiteram que a escolha entre os diferentes métodos na Análise Textual Discursiva possui uma relação com o fenômeno investigado, com objetivo da pesquisa, bem como o tipo de categoria, seja a priori e/ou emergente (SOUSA; GALIAZZI, 2017). 
Segundo Moraes e Galiazzi (2011), a terceira e última etapa da Análise Textual Discursiva consiste na produção dos metatextos, nos quais se expressam as compressões obtidas pelo pesquisador sobre o fenômeno em estudo. Para os autores, a produção dos metatextos pode se constituir de diferentes formas, envolvendo desde a escrita de textos com caráter descritivo àqueles com caráter interpretativo. Para os autores, a descrição está voltada ao sentido manifesto do corpus analisado, já na interpretação eles revelam a necessidade da abstração, para que então o pesquisador possa obter novas compreensões sobre a sua análise. Nesse processo, os autores revelam diferentes formas de teorização, sendo compreendidas nas teorias que emergem da análise e na ampliação daquelas já existentes. A validade dessa análise também é um aspecto apresentado pelos autores na construção dos metatextos, uma vez que para eles a validade está associada ao rigor metodológico do processo, bem como na construção de argumentos sobre a análise e no balizamento empírico, pois "se submetidos a críticas dos autores dos textos originais do 'corpus', estes precisam sentir-se contemplados nos resultados apresentados" (p. 39). Sousa e Galiazzi (2016) complementam ao afirmar que, independentemente do tipo de categoria trabalhada, a Análise Textual Discursiva busca a teoria, num processo de ampliação das compreensões sobre o que já é conhecido.

Neste contexto, sinalizam-se alguns avanços e complementaridades da Análise Textual Discursiva (MORAES; GALIAZZI, 2011) em relação à Análise de Prosa (ANDRÉ, 1983). Por exemplo, ao buscar por uma compreensão ampliada da Análise de Conteúdo, André (1983) ressalta a importância de considerar elementos implícitos da análise, os quais podem ser complementados pelos pressupostos que balizam o desenvolvimento da Análise Textual Discursiva. Outra complementaridade se apresenta na elaboração de categorias, visto que na Análise de Prosa não opera com categorias $a$ priori, o que poderia ser complementado pelo processo de categorização emergente da Análise Textual Discursiva. Dessa forma, a Análise Textual Discursiva pode conferir rigor metodológico à Análise de Prosa, preenchendo algumas das lacunas sinalizadas por André (1983), tais como o método adotado na categorização, a substituição do "critério de frequência" e a validação da análise. Isso porque, ao considerar a categorização emergente, o método indutivo e intuitivo ${ }^{12}$ da Análise Textual Discursiva prevaleceria, bem como a flexibilidade das unidades de análise auxiliariam na substituição do "critério

${ }^{12}$ É importante ressaltar que André (1983) considera a intuição e a subjetividade como fundamentais à análise, inclusive no que tange a sua validação. 
de frequência" que seriam validadas pelo rigor metodológico, na construção de argumentos e balizamento empírico, conforme orientam Moraes e Galiazzi (2011).

Os três aspectos sinalizados por André (1983) como fundamentais ao desenvolvimento de uma análise, também podem se aproximar da Análise Textual Discursiva. Como primeiro aspecto, André (1983) enfatiza que o processo de "coleta e análise" perpassa toda a análise, essa característica se apresenta na Análise Textual Discursiva por meio da adoção do critério de saturação que também exige de um processo contínuo de "coleta e análise", além de que essa forma de análise é essencialmente recursiva (MORAES; GALIAZZI, 2011). O segundo aspecto apresentado por André (1983) é a análise coletiva, a qual, apesar de não se constituir numa exigência da Análise Textual Discursiva, também não se apresenta como uma restrição, sendo, inclusive valorizada por estudos como Pedruzzi et al. (2015). O terceiro aspecto referido por André (1983, p. 70) sinaliza que "o que se procura obter num estudo é a compreensão ampla e profunda do objeto focalizado", esse aspecto está em sintonia com a Análise Textual Discursiva, a qual assume por foco, "geralmente a profundidade e complexidade dos fenômenos" (MORAES; GALIAZZI, 2011, p. 160). Além disso, outras questões metodológicas apontadas por André (1983), como a Credibilidade junto aos informantes, a Corroboração por parte de outro(s) analista(s) e a Triangulação, podem ser assumidas no desenvolvimento da Análise Textual Discursiva. Em síntese, diante das complementaridades e avanços sinalizados, compreende-se que a Análise Textual Discursiva se constitui numa concepção ampliada da Análise de Prosa, a qual sinaliza novos caminhos ao desenvolvimento da Investigação Temática.

\section{Articulações entre a Investigação Temática e a Análise Textual Discursiva}

No contexto da Educação em Ciências, algumas pesquisas têm buscado desenvolver articulações teórico-metodológicas de releituras do processo de Investigação Temática de Paulo Freire com a Análise Textual Discursiva, a exemplo de Milli, Solino e Gehlen (2018), Silva et al., (2017), Milli (2016), Milli et al., (2016), Oliveira e Recena (2009) e Torres et al., (2008). Essas pesquisas sinalizam contribuições da Análise Textual Discursiva no desenvolvimento de diversas etapas da Investigação Temática, tanto na obtenção dos Temas Geradores e ressignificação curricular quanto no desenvolvimento de atividades didático-pedagógicas. 
O trabalho de Torres et al., (2008) articula as três etapas da Análise Textual Discursiva com as cinco etapas da Investigação Temática (DELIZOICOV, 1991), as quais foram implementadas durante um processo de formação de educadores de uma escola pública localizada em Florianópolis/SC. Desta forma, os autores apresentam as seguintes articulações: a) Levantamento Preliminar/unitarização - consistiu na obtenção de informações com os educadores sobre a realidade local, por meio das quais foi estabelecido o corpus da análise e as unidades de sentido representativas de possíveis situações-limite; b) Análise das situações e escolha das codificações/categorização - as unidades de sentido foram reorganizadas de acordo com semelhanças semânticas, o que possibilitou a emergência de categorias das possíveis contradições sociais da comunidade; c) Diálogos descodificadores/categorização; as categorias emergentes foram problematizadas e legitimadas com a comunidade em Temas Geradores; d) Redução Temática e trabalho de sala de aula/metatexto - a elaboração do currículo por meio dos Temas Geradores, bem como a elaboração do material didático pedagógico e a efetivação de possíveis práticas na sala de aula, correspondeu à produção dos metatextos. Torres et al., (2008) ressaltam que a Análise Textual Discursiva utilizada no desenvolvimento das etapas da Investigação Temática contribui para a localização e análise dos problemas que permeiam a realidade da comunidade, além dos autores endossarem os aspectos teórico-metodológicos da construção de um currículo crítico.

Milli et al., (2016) baseiam-se no estudo de Torres et al., (2008) e buscam investigar contribuições das três etapas da Análise Textual Discursiva em cada etapa do processo de Investigação Temática sistematizada por Sousa et al., (2014) ${ }^{13}$. Esse estudo sinaliza alguns avanços ao trabalho de Torres et al., (2008), especialmente ao identificar diversas etapas da Análise Textual Discursiva na realização da Investigação Temática. As articulações propostas por Milli et al., (2016) podem ser sintetizadas da seguinte forma: a) Aproximações iniciais com a comunidade local e escolar - o grupo de estudo realizou um levantamento de informações na comunidade - blogs, sites, gravações, conversas, etc., as quais foram reunidas na forma do corpus de análise, sendo unitarizadas de acordo com possíveis situações-limite e categorizadas em grupos por semelhanças; b) Apresentação de possíveis situações-limite para a comunidade local as categorias elaboradas na primeira etapa da investigação foram problematizadas pelo grupo de estudo junto às educadoras, as quais selecionaram unidades de sentido e criaram

${ }^{13}$ Esse trabalho pauta-se em aproximações teórico-metodológicas da Investigação Temática de Delizoicov (1991) com os Momentos sistematizados por Silva (2004). 
novas categorias de análise, que foram apresentadas à comunidade e as suas compreensões representaram os metatextos; c) Legitimação da hipótese - essas compressões foram novamente problematizadas pelo grupo de estudos com as educadoras, legitimando um Tema Gerador, assim, a unitarização, a categorização e o metatexto se apresentam nesta etapa como sínteses de todo o processo; d) Organização da programação curricular/metatexto - os metatextos se apresentaram na produção de atividades didático-pedagógicas ${ }^{14}$.

Os trabalhos de Silva et al., (2017) e Oliveira e Recena (2009) também se utilizam da Análise Textual Discursiva durante a realização do processo de Investigação Temática. Porém, o estudo de Silva et al., (2017, p. 5) ressalta a utilização de uma questão como base para o desenvolvimento da investigação, a qual seja "Onde a Ciência pode ser encontrada em sua realidade e como tem contribuído ou poderá contribuir em suas atividades?". Do mesmo modo, Oliveira e Recena (2009, p. 3) partem de uma temática previamente estabelecida, a fim de “[...] conhecer as concepções dos alunos sobre a temática dos plásticos na busca de temas que serão, no decorrer do desenvolvimento da proposta, descodificadas por alunos e professores, culminando posteriormente na redução temática". Nesses trabalhos, a Análise Textual Discursiva foi utilizada como forma de encaminhar a análise das informações do contexto investigado, tendo em vista elementos pré-fixados. É importante ressaltar que Freire (1987) não considera o uso de "pontos préfixados" durante a investigação, atitude atribuída por ele a uma visão focalista na qual os “investigadores que se julgam a si mesmos os sujeitos exclusivos da investigação." (p. 57). Neres e Gehlen (2018) corroboram com essa compreensão e salientam que esses pontos podem propiciar uma visão parcial e simplista sobre os problemas da comunidade.

Milli (2016) e Milli, Solino e Gehlen (2018) estabelecem e aprofundam relações entre a Análise Textual Discursiva e o processo de Investigação Temática. O estudo de Milli (2016) pauta-se na realização de um processo educativo com educadoras do ensino fundamental de ciências do município de Santa Luzia/BA, estabelece critérios teóricometodológicos em cada etapa da Investigação Temática por meio da Análise Textual Discursiva e busca superar uma visão focalista da investigação (FREIRE, 1987). Milli, Solino e Gehlen (2018) ampliam as articulações do estudo de Milli (2016) com a criação de "parâmetros analíticos" para a etapa de Levantamento Preliminar da Investigação

\footnotetext{
${ }^{14}$ Os autores também identificam algumas relações da Análise Textual Discursiva com a dinâmica dos Momentos Pedagógicos de Delizoicov, Angotti e Pernambuco (2011).
} 
Temática. Além disso, os autores explicitam aspectos ontológicos desse processo de investigação e destacam que:

Nesse movimento, as subjetividades das informações, carregadas de sentidos e valores, transformam o olhar dos investigadores para além da objetividade e daquilo que se mostra na aparência dos fatos, possibilitando captar o novo emergente (Moraes \& Galiazzi, 2011), ou melhor, o inédito viável (Freire, 1987), muitas vezes camuflado na complexidade das contradições sociais vivenciadas pelos sujeitos (MILLI; SOLINO; GEHLEN, 2018, p.225-226).

Os aspectos salientados por Milli, Solino e Gehlen (2018) indicam potencialidades da Investigação Temática, articulada com a Análise Textual Discursiva, para a apreensão da realidade entre aspectos objetivos e subjetivos (FREIRE, 1987). Uma vez caracterizadas, essas relações podem ser ampliadas às demais etapas da Investigação Temática e explicitadas em seu potencial teórico-metodológico.

\section{A Investigação Temática e a Análise Textual Discursiva: no caos de uma tempestade}

Para Freire (1987), a luta pela humanização dos seres humanos, a libertação de seu estado de opressão e mudança das estruturas sociais possuem uma dimensão subjetiva e outra objetiva que não podem ser compreendidas separadamente ou terem sua existência negada. Dessa forma, o autor considera a relação permanente e dialética entre subjetividade e objetividade como exigência à análise crítica da realidade. Em razão disso, Freire (1987) critica o "simplismo ingênuo", que desconsidera a relação homemmundo e considera que a realidade é tanto produto quanto base de transformação das ações históricas dos seres humanos. O autor também salienta que a relação entre objetividade e subjetividade se expressa no diálogo, uma vez que a prática libertadora não se faz da consciência dos investigadores sobre a realidade, tampouco daquilo que almejam a essa realidade, conforme o mesmo destaca:

\footnotetext{
Esta prática implica, por isto mesmo, em que o acercamento às massas populares se faça, não para levar-lhes uma mensagem "salvadora", em forma de conteúdo a ser depositado, mas, para, em diálogo com elas, conhecer, não só a objetividade em que estão, mas a consciência que tenham desta objetividade; os vários níveis de percepção de si mesmos e do mundo em que e com que estão (FREIRE, 1987, p. 49).
}

Freire (1987) discute que a prática libertadora, tanto no contexto pedagógico como de ação política, consiste num "autêntico" e constante diálogo com as massas, estabelecido na percepção dos oprimidos sobre si e sobre a realidade na qual se encontram e concretizam a busca do "ser mais" (FREIRE, 1987). Para Stuani (2016), a busca do ser 
mais fundamenta a dimensão ontológica em Freire, de modo que o sujeito é concebido em sua potencialidade de transformar criticamente o mundo. A autora ainda discute que essa dimensão ontológica se inter-relaciona com a dimensão gnosiológica, a qual está presente no diálogo entre diferentes conhecimentos e práticas necessárias à superação da realidade concreta, ou seja, da própria busca do ser mais (STUANI, 2016). Dessa forma, a inter-relação entre as dimensões ontológicas e gnosiológicas, também é reflexo da relação entre objetividade e subjetividade, que culmina na práxis autêntica (STUANI, 2016; FREIRE, 1987).

Para Brick (2017), a compreensão dialética entre objetividade e subjetividade, presente na perspectiva freireana de educação, não dissocia as determinações sociais de suas influências na formação da consciência, nem supervaloriza um aspecto em relação a outro, de modo que tanto o fenômeno quanto a essência são elementos intrínsecos à realidade. $\mathrm{O}$ autor defende que os Temas Geradores, no que tange à relação intersubjetiva e objetiva de sua obtenção, necessitam ter por referência a totalidade concreta que representam e se integram (BRICK, 2017). No Caderno de Formação 02 (SÃO PAULO, 1990b) há outro exemplo da importância dos aspectos subjetivos e objetivos envolvendo o processo de análise de informações pela Investigação Temática. É, portanto, ressaltado que nenhuma análise é neutra ou absolutamente objetiva, de modo que os valores daqueles que investigam a realidade, suas potencialidades e limitações não constituem apenas sua subjetividade, mas se constitui como parte fundamental do coletivo que investiga e da própria investigação (SÃO PAULO, 1990b).

O documento deixa expresso ainda que a realidade investigada é fundamentalmente uma realidade parcial, produto da subjetividade em interação com a objetividade. Para análise dessa interação, apresenta dois procedimentos e um indicador, quais sejam: a) trabalho coletivo e interdisciplinar - possibilita uma análise ampla, compreendendo as diferentes visões, de diferentes contextos, sobre a realidade; b) "Atitude de estranhamento" 15 - constitui-se no "estranhar", questionar o óbvio e familiar num amplo prisma de possibilidades. Já o indicador implica em considerar na análise o “conteúdo não manifesto", ou seja, aquilo que não está oculto, "por de trás” das informações da comunidade ${ }^{16}$ (SÃO PAULO, 1990b).

\footnotetext{
15 O Caderno de Formação 02 (SÃO PAULO, 1990b, p. 50) apresenta em nota esse termo com base no trabalho de "Marli E. D. Afonso de no texto A pesquisa do tipo etnológico no cotidiano escolar in Metodologia da Pesquisa Educacional de Invani C. A. Fazenda (org.), São Paulo, Cortez Editora, 1989.”.

${ }^{16}$ Sob tal aspecto, o Caderno de Formação 02 (SÃO PAULO, 1990b) pauta-se no trabalho de André (1983).
} 
É possível compreender essas discussões sob o ponto de vista da epistemologia de Fleck (2010), para o qual o conteúdo do conhecimento se expressa por meio de relações passivas e ativas. Aquelas que não possuem uma explicação psicológica ou histórica são denominadas pelo autor de relações passivas e as que se explicam no desenvolvimento histórico e cultural são por ele denominadas de relações ativas. Fleck (2010) acentua que a junção dos fenômenos que se explicam historicamente forma o acoplamento ativo dos fenômenos, que de forma análoga, se contrapõe aos acoplamentos passivos. Nesse sentido, o autor considera que no processo de conhecimento de algo existem resultados já esperados em condições específicas, as quais representam os acoplamentos ativos a serem verificados pelo indivíduo, bem como constituem a realidade objetiva (FLECK, 2010). Exemplo:

[...] a relação entre a massa atômica do oxigênio e a do hidrogênio, 16:1008, como um número que resulta de maneira passiva sob determinadas condições. Se alguém conseguisse decompor o oxigênio em dois elementos, esse número seria explicado como decorrente da insuficiência do método antigo e teria de ser substituído por outro número (FLECK, 2010, p. 145).

Por meio desse exemplo, Fleck (2010) chama a atenção que as relações passivas de um fato podem ser transformadas em ativas, desde que as condições ativas que determinam o fato (passivo) variem. $\mathrm{O}$ autor argumenta que as relações passivas e ativas se interconectam e se transformam, estando sempre acompanhadas umas das outras. Brick (2017) reafirma tais aspectos ao considerar que a mediação ao objeto do conhecimento na epistemologia de Fleck ocorre pela relação objetiva e subjetiva, sem que haja a dicotomia do fenômeno e sua essência (BRICK, 2017).

A relação entre objetividade e subjetividade também está presente na Análise Textual Discursiva. De acordo com Moraes e Galiazzi (2011), o movimento que se estabelece entre esses pólos constitui-se como características das análises textuais, de modo que Análise Textual Discursiva possui uma inclinação aos aspectos subjetivos, tendo em vista a busca no processo de investigação a originalidade e criatividade. Apesar de compreender aspectos objetivos, os autores enfatizam que ao definir uma postura mais subjetiva na análise, as categorias orientam-se pelo corpus da análise, do qual emergem. Os autores discutem que esse movimento de busca por se aprofundar sobre o material analisado na busca por novos sentidos e significados tem sido uma tendência das análises textuais, exigindo, também, um maior comprometimento, envolvimento e respeito do pesquisador com seu trabalho. Nisto, o vínculo do pesquisador com o fenômeno, como 
parte do processo e produto de seu estudo, possui relação explícita com a hermenêutica (SOUSA; GALIAZZI; SCHMIDT, 2016).

Na busca pelos sentidos e significados, Moraes e Galiazzi (2011) consideram que a Análise Textual Discursiva é orientada pelos princípios da hermenêutica, que visa reconstruir os significados sociais sob a ótica interpretativa dos fenômenos investigados. Para tal, os autores sinalizam como ponto de partida a busca pelos sentidos que mais se evidenciam nos fenômenos, para então mergulhar na complexidade de suas relações, reconstruindo os significados. Sousa, Galiazzi e Schmidt (2016) descrevem esse processo da seguinte forma:

A ATD inicia imersa na ideia de interjogo entre as partes e o todo, não no sentido de que este todo é alcançado pela é a soma matemática das partes, mas se vincula a ideia de que para compreender o todo é preciso reconhecer e interpretar as partes como primeiro movimento (SOUSA; GALIAZZI; SCHMIDT, 2016, p. 325).

Sousa, Galiazzi e Schmidt (2016) defendem o movimento circular e hermenêutico da Análise Textual Discursiva que busca a ampliação das compreensões sobre o fenômeno investigado. Nesse processo de análise, especialmente de construção e legitimação das categorias, Moraes e Galiazzi (2011) consideram a importância de dois aspectos: i) a relação com o contexto - as categorias necessitam estar articuladas com o corpus de origem, com a produção deste, bem como os sentidos e significados que expressam e ii) a relação com os objetivos - é necessária a coerência entre objetivos da pesquisa e suas categorias, mesmo que ambos se reformulem durante a análise, devem-se manter relacionados. Esses dois aspectos reafirmam a relação entre objetividade e subjetividade da Análise Textual Discursiva, tanto pela ênfase no contexto quanto nos objetivos da pesquisa, uma vez que remetem a busca pelos diversos sentidos e significados em coerência com o seu movimento histórico (SOUSA; GALIAZZI, 2017; MORAES; GALIAZZI, 2011).

Moraes e Galiazzi (2011) também argumentam que a Análise Textual Discursiva não se constitui somente na busca da expressão da realidade em si, pois a partir dessa expressão há a exigência por sua reconstrução e transformação, num processo em que haja a articulação da hermenêutica com a dialética. A dialética se apresenta, portanto, como resultado das relações de oposição entre objetividade e subjetividade que se unem por meio dessa ferramenta metodológica, tanto por uma teoria definida a priori quanto pelas emergentes (SOUSA; GALIAZZI, 2017). Moraes e Galiazzi (2011) ainda esclarecem que a transformação que se exige na Análise Textual Discursiva é estabelecida 
pelas novas compreensões que se obtém na análise. Por isso, outro fator importante a se ressaltar é a perspectiva política presente nessa metodologia, uma vez que:

Dependendo dos pressupostos assumidos, a análise pode ter diferentes encaminhamentos e resultados. Esses pressupostos podem ser de natureza ontológica, epistemológica e axiológica, correspondendo a modos de entender a realidade, a produção de conhecimentos e valores (MORAES; GALIAZZI, 2011, p. 135).

Dessa forma, complementa-se:
A qualidade política, entretanto, depende dos pressupostos assumidos pelo pesquisador em seu trabalho, especialmente ao se assumir como sujeito histórico, capaz de intervir nos discursos no sentido de sua reconstrução (MORAES; GALIAZZI, 2011, p. 137).

Os aspectos destacados da Análise Textual Discursiva convergem a uma determinada liberdade do pesquisador em assumir diferentes posturas na investigação, porém, essas ações reverberam na qualidade política de intervenção nos discursos (PEDRUZZI et al., 2015; MORAES; GALIAZZI, 2011). Assim, se pelo lado da hermenêutica exige-se da análise a ampliação das compreensões (SOUSA; GALIAZZI, 2016), pelo lado da dialética exige-se à relação entre objetividade e subjetividade (SOUSA; GALIAZZI, 2017). Dito isto, em que aspectos essa ferramenta complementa ou se inter-relaciona com a Investigação Temática?

\subsection{Os potenciais teórico-metodológicos da Investigação Temática articulada a}

\section{Análise Textual Discursiva}

Das discussões teóricos-metodológicas entre a Análise Textual Discursiva e a Investigação Temática, destacam-se alguns pontos fundamentais, denominados de potenciais, quais sejam: potencial metodológico, potencial hermenêutico e o potencial dialético $^{17}$.

a) O potencial metodológico - a fundamentação metodológica da Investigação Temática sinaliza fragilidades, em especial, no processo de análise de informações. Essa fragilidade se evidencia quando os Cadernos de Formação 02 (SÃO PAULO, 1990b) sugerem a utilização da Análise de Prosa (ANDRÉ, 1983) como forma de nortear o estudo dos diversos sentidos e significados advindos das informações da realidade. Ainda, assim, situada no âmbito dos questionamentos metodológicos qualitativos da década de 1980, a Análise de Prosa (ANDRÉ, 1983) constitui-se apenas como uma perspectiva

\footnotetext{
${ }^{17}$ Stuani (2016) também identifica alguns potenciais relativos à perspectiva freireana de educação, como o potencial praxiológico, ontológico, etc.
} 
metodológica, sem que haja um processo ou encaminhamento analítico bem definido. A falta deste delineamento metodológico reforça a utilização da Análise Textual Discursiva no processo de Investigação Temática, caminho este discutido nas seções anteriores.

b) O potencial hermenêutico - A Análise Textual Discursiva se encontra atrelada a uma perspectiva hermenêutica de análise, na compreensão histórica do fenômeno e ampliação de sua compreensão pela interpretação da realidade e reconhecimento de sua diversidade, constituída numa interpretação fenomenológica (SOUSA; GALIAZZI, 2016; SOUSA; GALIAZZI; SCHMIDT, 2016; SOUSA; GALIAZZI, 2017). Essa perspectiva hermenêutica e fenomenológica da Análise Textual Discursiva pode contribuir com o desenvolvimento da Investigação Temática como forma de auxiliar no estudo interpretativo dos níveis de percepção que os sujeitos possuem sobre si e sobre a realidade, sendo esta uma exigência da Investigação Temática (FREIRE, 1987). Sousa, Galiazzi e Schmidt (2016) defendem que o movimento circular e hermenêutico da Análise Textual Discursiva, na relação parte-todo, possibilita a ampliação das compreensões estabelecidas durante a análise. Porém, Fernández Rodríguez e Gutiérrez Pequeño (2014) tecem severas críticas a perspectiva hermenêutica e destacam:

\begin{abstract}
Em última análise, e em relação à posição do tradutor (leia educador), vamos cuidar de muitos agentes conscientizadores de ser nada mais que "pequenos Hermes" que tentam (em vão) comunicar o mundo dos Deuses com o dos mortais. Preocupemo-nos, antes, em desobstruir os nossos ouvidos («surdez cultural») e abrir os olhos («cegueira ideológica»), para que essas «negatividades radicais» continuem a preferir o mundo dos mortais e devolvam aos educadores críticos, para vê-los apenas como "aprendizes de pequenos deuses". Vamos ter cuidado, então, de «não converter negatividades em falsos antagonismos», esta é a chave (FERNÁNDEZ RODRÍGUEZ; GUTIÉRREZ PEQUEÑO, 2014, p. 82-83, tradução nossa).
\end{abstract}

Valendo-se da metáfora do deus Hermes, Fernández Rodríguez e Gutiérrez Pequeño (2014) discutem a importância de um posicionamento crítico que não se restrinja à simples comunicação. Os autores também argumentam que a hermenêutica na perspectiva de educação emancipadora se apresenta de forma frágil, sem que haja uma reflexão acerca das tensões sociais de modo que os mapas da realidade precedam o lugar que se investiga ${ }^{18}$. Corroborando a esta crítica metafórica, ou endossando esse "conflito de deuses", ressalta-se que para Moraes e Galiazzi (2011) a Análise Textual Discursiva se apresenta em duas faces, como o deus Jano, sendo elas a aprendizagem e a comunicação. Os autores consideram que no desenvolvimento da Análise Textual

\footnotetext{
${ }^{18}$ Com base nos estudos de Gatti (1999 apud FERNÁNDEZ RODRÍGUEZ; GUTIÉRREZ PEQUEÑO, 2014), Fernández Rodríguez e Gutiérrez Pequeño (2014) utilizam essa metáfora como forma de criticar o positivismo.
} 
Discursiva, perpassando os momentos de descrição, de interpretação e de argumentação, inter-relacionados, possibilitam "tanto a comunicação dos resultados quanto possibilitará novas aprendizagens sobre os fenômenos investigados" (p. 97). Moraes e Galiazzi (2011) também se valem da metáfora da produção de mapas a fim de explicar a relação entre aprender e comunicar presente na Análise Textual Discursiva. Mapas esses que se constroem ao longo da análise à medida que se conhece a realidade, o conhecimento se constitui na aprendizagem sobre a realidade e se expressa na produção do mapa (MORAES; GALIAZZI, 2011).

c) O potencial dialético - Além de sua orientação sob o viés hermenêutico, a Análise Textual Discursiva também se constitui sob aspectos da dialética (MORAES; GALIAZZI, 2011; SOUSA; GALIAZZI, 2017). Essa dialética se mostra no seu olhar crítico, que não busca apenas expressar a realidade em si, mas produzi-la e reconstruí-la, sem dissociar da hermenêutica, orientada para produção de novas compreensões (MORAES; GALIAZZI, 2011; SOUSA; GALIAZZI, 2017). Para exemplificar o potencial da Análise Textual Discursiva, Moraes e Galiazzi (2011) a compara com uma tempestade de luz e explicam:

\footnotetext{
Esse processo em seu todo é comparado a uma tempestade de luz. Consiste em criar as condições dessa tempestade em que, emergindo do meio caótico e desordenado, formam-se "flashes" fugazes de raios de luz sobre os fenômenos investigados, que, por meio de um esforço de comunicação intenso, possibilitam expressar novas compreensões alcançadas ao longo da análise (MORAES; GALIAZZI, 2011, p. 12-13).
}

Por meio dessa metáfora, os autores entendem o processo de análise como uma tempestade, que em meio ao caos e escuridão, surgem flashes de luz que permitem a visualização da paisagem, ou melhor, do fenômeno. No entanto, só a luz de uma tempestade que ilumina a realidade não é suficiente à sua transformação, mas a vertente dialética combinada com a hermenêutica da Análise Textual Discursiva pode auxiliar na produção e reconstrução de conhecimentos e práticas (AULER; DELIZOICOV, 2015). Ainda, assim, apenas a produção de novos conhecimentos não é suficiente à superação de uma totalidade concreta (BRICK, 2017), pois, da relação entre objetividade e subjetividade da perspectiva emancipadora freireana, que não considera a dissociação entre fenômeno e essência (BRICK, 2017) e que se constitui da inter-relação das dimensões ontológicas e gnosiológicas na busca do "Ser mais" (STUANI, 2016), tem-se a exigência da práxis autêntica (STUANI, 2016; FREIRE, 1987). Por isso, pode-se complementar a metáfora da tempestade de luz, uma vez que depois dos raios de luzes 
que permitem a percepção da realidade, surgem os trovões, os quais orientam a transformação da realidade.

Em resumo, a Análise Textual Discursiva, ao combinar a hermenêutica com a dialética (MORAES; GALIAZZI, 2011), pode auxiliar na operacionalização da Investigação Temática e servir à investigação como uma bússola praxiológica ${ }^{19}$, que não só direciona os investigadores ao novo, como também constrói seus mapas (FERNÁNDEZ RODRÍGUEZ; GUTIÉRREZ PEQUEÑO, 2014; MORAES; GALIAZZI, 2011). Assim, destaca-se a necessidade da qualidade e compromisso político da Análise Textual Discursiva para o encaminhamento de ações transformadoras da realidade, conforme orientam Moraes e Galiazzi (2011) e Fernández Rodríguez e Gutiérrez Pequeño (2014).

Síntese das contribuições da Análise Textual Discursiva ao processo de Investigação Temática podem ser visualizadas no Quadro 2, a seguir:

Quadro 2: Potenciais da Análise Textual Discursiva na Investigação Temática

\begin{tabular}{|c|c|c|}
\hline Potencial Metodológico & Potencial Hermenêutico & Potencial Dialético \\
\hline $\begin{array}{l}\text { As informações obtidas durante } \\
\text { o processo de Investigação } \\
\text { Temática podem ser analisadas à } \\
\text { luz das etapas da Análise Textual } \\
\text { Discursiva. }\end{array}$ & $\begin{array}{l}\text { Auxilia o investigador a construir } \\
\text { interpretações dos níveis de } \\
\text { percepção que os sujeitos } \\
\text { possuem sobre si e sobre a } \\
\text { realidade. Ou seja, ajuda a } \\
\text { subsidiar o processo de } \\
\text { identificação e compreensão das } \\
\text { situações-limites vivenciadas } \\
\text { pelos sujeitos. }\end{array}$ & $\begin{array}{l}\text { Auxilia o investigador não } \\
\text { somente a expressar a realidade } \\
\text { analisada, mas produzi-la e } \\
\text { reconstruí-la junto aos sujeitos } \\
\text { envolvidos no processo. }\end{array}$ \\
\hline
\end{tabular}

Fonte: autores

Destaca-se, aqui, que algumas pesquisas já têm contemplado esses Potenciais da Análise Textual Discursiva na Investigação Temática. O estudo de Torres et al. (2008) foi o primeiro a apresentar elementos que contribuem para configurar a ATD como sendo uma bússola praxiológica da Investigação Temática, especialmente pelo fato dela ter possibilitado, no contexto formativo de professores, a sistematização do processo de interpretação das falas dos sujeitos envolvidos na investigação do Tema Gerador, bem como a reflexão dos educadores sobre a produção de conhecimentos no âmbito das suas práticas pedagógicas (TORRES et al., 2008).

19 Termo inspirado em Silva (2004), o qual destaca o papel da "bússola pedagógica" na organização curricular, bem como em Stuani (2016) que argumenta sobre a práxis. 
O trabalho de Milli, Solino e Gehlen (2018) avança nessa configuração da ATD, a qual passa a ter uma função importante na sistematização do Levantamento Preliminar - primeira etapa da Investigação Temática - e apresenta parâmetros analíticos que podem contribuir na organização e desenvolvimento de processos formativos de educadores de ciências, bem como na sistematização de programas escolares. Tais parâmetros permitem evidenciar as possíveis situações-limites de uma determinada comunidade para além da aparência dos fatos, possibilitando captar o novo emergente, isto é, orientando caminhos para a transformação da realidade.

\section{Encaminhamentos à pesquisa e algumas considerações}

No presente estudo, foram analisadas as aproximações e complementaridades da realização da Análise Textual Discursiva na Investigação Temática. Dessa forma, apresentou-se a constituição da Investigação Temática e o seu processo de sistematização para o âmbito escolar (NERES; GEHLEN, 2018; DELIZOICOV, 2008), dando-se ênfase para as contribuições teórico-metodológicas do Movimento de Reorientação Curricular (SÃO PAULO, 1990a, 1990b, 1991; BRASIL, 1994), especialmente no que tange a utilização da Análise Prosa na interpretação dos dados da Investigação Temática (ANDRÉ, 1983).

Nesse contexto, a Análise Textual Discursiva (2011) foi compreendida como uma concepção ampliada da Análise de Prosa (ANDRÉ, 1983). Assim, são apresentadas as suas potencialidades, caracterizadas em três aspectos: a) $O$ potencial metodológico; $b$ ) $O$ potencial hermenêutico; c) O potencial dialético. Diante esses potenciais, argumenta-se que a Análise Textual Discursiva pode ser compreendida como uma bússola praxiológica da Investigação Temática, a qual aponta o caminho à práxis, seja no reconhecimento ou na produção de novos conhecimentos necessários à transformação da realidade (MORAES; GALIAZZI, 2011; FERNÁNDEZ RODRÍGUEZ; GUTIÉRREZ PEQUEÑO, 2014; AULER; DELIZOICOV, 2015; STUANI, 2016; AULER, 2018).

Neste estudo, são sinalizadas, por meio de algumas metáforas, os sentidos e significados mais profundos que emergem da Análise Textual Discursiva. Os flashes de luz decorrentes de sua tempestade têm guiado e orientado o caos de diversos pesquisadores. Todavia, alerta-se a esses, iniciantes e experientes, que dos raios advêm os trovões! Essa é uma das exigências que faz a realização da Análise Textual Discursiva na Investigação Temática. Em termos freireanos, sobre a necessidade da denúncia e do 
anúncio em relação às contradições sociais, os flashes denunciam essas contradições, já os trovões anunciam a sua transformação (STUANI, 2016; SILVA, 2004). Essa não é só a razão da realização da Investigação Temática - de buscar a superação das contradições sociais, mas também das pesquisas que se comprometem com a perspectiva freireana de educação (ALVES; SILVA, 2015).

Guiar-se sob uma tempestade não é fácil, assim como assumir os pressupostos freireanos também não é, por isso que se apresenta e se reafirma o uso da Análise Textual Discursiva enquanto bússola praxiológica da Investigação Temática, direcionando investigadores à produção de novos conhecimentos que auxiliem na busca pela transformação da realidade. Não se busca restringir os potenciais dessa ferramenta e nem, tampouco, afirmá-la como única passível de articular-se à Investigação Temática - a articulação com a Análise de Prosa já se mostra como um exemplo. Porém, é imperativo ressaltar que esta relação com a Investigação Temática está situada no âmbito da práxis, que não é uma ação ativista, tampouco um discurso falacioso, mas um compromisso político com a transformação da realidade (FREIRE, 1987). Essa é a conclusão pela qual se justifica o uso da Análise Textual Discursiva na Investigação Temática e nas pesquisas comprometidas com os ideais freireanos, pois essa é uma ferramenta que se mostra aberta à realização da práxis, tanto por sua organização metodológica quanto por suas relações hermenêuticas, fenomenológicas e dialéticas.

Seria ingênuo ou até mesmo distante da humildade epistemológica prezada por Paulo Freire não reconhecer os limites presentes na proposição deste estudo (ALVES; SILVA, 2015). Dessa forma, sinaliza-se a necessidade de ampliar essas discussões do ponto de vista teórico e também empírico. Teórico, no sentido de explicitar outros elementos da Análise Textual Discursiva que convergem com os fundamentos da perspectiva freireana, a exemplo de algumas discussões marxistas. De acordo com Gonçalves (2020), isso não significa que os estudos têm atuado num “vácuo teórico", mas há necessidade de explicitar um alinhamento entre os pressupostos teóricos e metodológicos das pesquisas. E do ponto de vista empírico, é importante ampliar a utilização das etapas da Análise Textual Discursiva junto aos processos formativos de professores buscando, cada vez mais, uma formação permanente e colaborativa entre professores, pesquisadores e comunidades locais, ultrapassando os muros da Universidade e Escola. Em suma, há necessidade de um maior aprofundamento teóricometodológico que compreenda, exerça e assuma a Análise Textual Discursiva no âmbito da práxis. 


\section{Agradecimentos}

Agradecemos ao CNPq e a Capes pelo apoio financeiro, sob o processo $\mathrm{n}^{\circ}$ 88887.373148/2019-00.

\section{Referências}

ALVES, A. H. B.; SILVA, A. F. G. da. Manifestações de Obstáculos Gnosiológicos para a Seleção de Conteúdos na Implementação de um Currículo Crítico em Ciências Naturais. Alexandria: Revista de Educação em Ciência e Tecnologia, Florianópolis, v.8, n.1, p.181-207, maio. 2015.

ANDRÉ, M. E. D. A. de. Texto, Contexto e Significado: algumas questões na análise de dados qualitativos. Caderno de Pesquisa, São Paulo, n. 45, p. 66-71, maio. 1983.

AULER, D. Cuidado! Um cavalo viciado tendo a voltar para o mesmo lugar. Curitiba: Appris, 2018.

AULER, D.; DELIZOICOV, D. Investigação de temas CTS no contexto do pensamento latinoamericano. Linhas Críticas, Brasília, v.21, n.45, p. 275-296, mai./ago. 2015.

BRASIL. Ministério da Educação e Cultura. Instituto Nacional de Estudos e Pesquisas Educacionais - INEP. Interdisciplinaridade no município de São Paulo. Série inovações educacionais: 3. Brasília: INEP, 1994.

BRICK, E. M. Realidade e Ensino de Ciências. 2017. Tese (Doutorado em Educação Científica e Tecnológica) - Centro de Ciências da Educação da Universidade Federal de Santa Catarina.Programa de Pós-Graduação em Educação Científica e Tecnológica/UFSC, Florianópolis, 2017.

DELIZOICOV, D; ANGOTTI, J. A.; PERNAMBUCO, M. M. Ensino de Ciências: fundamentos e métodos. 4. ed. São Paulo: Cortez, 2011.

DELIZOICOV, D.; DELIZOICOV, N. C.; SILVA, A. F. G. da. Paulo Freire e o ser humano em processo de formação permanente. Retratos da Escola, Brasília, v.14, n.29, p. 353-369, maio/ago. 2020.

DELIZOICOV, D. La Educación en Ciencias y la Perspectiva de Paulo Freire. Alexandria: Revista de Educação em Ciência e Tecnologia, Florianópolis, v.1, n.2, p.37-62, jul. 2008.

DELIZOICOV, D. Concepção Problematizadora do Ensino de Ciências na Educação Formal. 1982. Dissertação (Mestrado em Ensino de Física) - Instituto de Física, Universidade de São Paulo. IF/USP, São Paulo, 1982.

DELIZOICOV, D. Conhecimento, tensões e transições. 1991. Tese (Doutorado em Educação) - Faculdade de Educação, Universidade de São Paulo, São Paulo, 1991.

DELIZOICOV, N. C.; STUANI, G. M.; CUNHA, S. L. da. (org.). A Atualidade das Ideias de Paulo Freire. Toledo: Editora VIVENS, 2018.

FERNÁNDEZ RODRÍGUEZ, E.; GUTIÉRREZ PEQUEÑO, J. M. Releyendo la metodología de la Investigación-Acción Participativa (IAP). Pedagogía de las ausencias, Pedagogía de la 
traducción y Pedagogía de la articulación. Revista Electrónica Interuniversitaria de

Formación del Profesorado (REIFOP), Zaragoza, Espanha, v.17, n.1, p. 73-85, jan-abr. 2014.

FLECK, L. Gênese e desenvolvimento de um fato científico. Tradução de Georg Otte e Mariana Camilo de Oliveira. 1 a Edição. Belo Horizonte: Fabrefactum, 2010.

FREIRE, P. Pedagogia do oprimido. 17. ed. Rio de Janeiro: Paz e Terra, 1987.

FREIRE, P. Conscientização - teoria e prática da libertação: uma introdução ao pensamento de Paulo Freire. São Paulo: Cortez \& Moraes, 1979.

FREIRE, P. Educação como prática da liberdade. Rio de Janeiro: Paz e Terra, 1967.

GONÇALVES, F. P. Considerações de natureza epistemológica sobre a análise textual discursiva. Educação, Porto Alegre, v. 43, n. 1, p. 1-12., jan./abr., 2020.

MILLI, J. C. L. Análise Textual Discursiva: um caminho na investigação do Tema Gerador para o Ensino de Ciências/Física. 2016. Graduação (Graduação em Licenciatura em Física) Departamento de Ciências Exatas e Tecnológicas, Universidade Estadual de Santa Cruz/UESC, Ilhéus, 2016.

MILLI, J. C. L.; SOLINO, A. P.; GEHLEN, S. T. A Análise Textual Discursiva na investigação do Tema Gerador: por onde e como começar? Investigações em Ensino de Ciências, Porto Alegre, v. 23, n.1, p. 200-229, abr. 2018.

MILLI, J. C. L. et al. A Análise Textual Discursiva na identificação de situações-limites: contribuições do Ensino de Ciências/Biologia. Revista da SBEnBio, Maringuá/PR, n. 9, p. 6296-6308, outubro. 2016.

MORAES, R. Uma tempestade de luz: a compreensão possibilitada pela Análise Textual Discursiva. Ciência \& Educação, Bauru, v. 9, n. 2, p. 191-211. 2003.

MORAES, R.; GALIAZZI, M. do C. Análise Textual Discursiva. 2. ed. Ijuí: UNIJUÍ, 2011.

MUENCHEN, C. A disseminação dos Três Momentos Pedagógicos: um estudo sobre práticas docentes na região de Santa Maria/RS. 2010. Tese (Doutorado em Educação

Científica e Tecnológica) - Centro de Ciências da Educação, Universidade Federal de Santa

Catarina. Programa de Pós-Graduação em Educação Científica e Tecnológica PGECT/UFSC, Florianópolis, 2010.

MUENCHEN, C.; DELIZOICOV, D. A construção de um processo didático-pedagógico dialógico: aspectos epistemológicos. Ensaio, Belo Horizonte, v.14, n. 3, p. 199-2015, set./dez. 2012.

NERES, C. A.; GEHLEN, S. T. Investigação Temática na Formação de Professores: Indicativos da Pesquisa em Educação em Ciências. Revista Brasileira de Pesquisa em Educação em Ciências, Belo Horizonte, v. 18, n. 1, p. 239-267, abr. 2018.

NERES, C. A. O processo de Investigação Temática no contexto da formação de professores de Ciências: um olhar a partir de Fleck. 2016. Dissertação (Mestrado em Educação em Ciências) - Departamento de Ciências Exatas e Tecnológicas, Universidade Estadual de Santa Cruz/UESC, Ilhéus, 2016.

OLIVEIRA, A. M. de; RECENA, M. C. P. A Investigação Temática e a Análise Textual Discursiva: busca por Temas Geradores. In: ENCONTRO NACIONAL DE PESQUISA EM 
EDUCAÇÃO EM CIÊNCIAS, 7., 2009, Florianópolis, Anais... ABRAPEC: Florianopólis, 2009. p. 1-12.

PEDRUZZI, A. das N. et al. Análise Textual Discursiva: os movimentos da metodologia de pesquisa. Atos de Pesquisa em Educação, Blumenau, v. 10, n.2, p.584-604, mai./ago. 2015.

PONTUSCHKA, N. (org.) Ousadia no diálogo - Interdisciplinaridade na escola pública. São Paulo: Edições Loyola, 1993.

PORTO, R. de C. C.; LIMA, T. S. de. O legado de Paulo Freire para a formação permanente: uma leitura crítica das dissertações e teses sobre a formação de professores. Revista eCurriculum, São Paulo, v. 14, n. 1, p. 186-210, jan./mar. 2016.

SÃO PAULO. Secretaria Municipal de Educação. Um primeiro olhar sobre o projeto. Cadernos de Formação 01. Série: Ação pedagógica da escola pela via da interdisciplinaridade. São Paulo: DOT/SME-SP, 1990a. 59p.

SÃO PAULO. Secretaria Municipal de Educação. Estudo preliminar da realidade local: resgatando o cotidiano. Cadernos de Formação 02. Série: Ação pedagógica da escola pela via da interdisciplinaridade. São Paulo: DOT/SME-SP, 1990b. 63p.

SÃO PAULO. Secretaria Municipal de Educação. Tema Gerador e a construção do programa: uma nova relação entre currículo e realidade. Cadernos de Formação 03. Série: Ação pedagógica da escola pela via da interdisciplinaridade. São Paulo: DOT/SME-SP, 1991. $35 \mathrm{p}$.

SAUL. A. M. Paulo Freire na atualidade: legado e reinvenção. Revista e-Curriculum, São Paulo, v.14, n.1, p.09-34, jan./mar. 2016.

SAUL, A. M.; SILVA, A. F. G. O legado de Paulo Freire para as políticas de currículo e para a formação de educadores no Brasil. Revista Brasileira de Estudos Pedagógicos, Brasília, v.90, n.224, p. 223-244, jan./abr. 2009.

SAUL, A. M.; SILVA, A. F. G. O pensamento de Paulo Freire no campo de forças das políticas de currículo: a democratização da escola. Revista e-Curriculum, São Paulo, v.7, n.3, p. 1-24, dez. 2011.

SILVA, A. L. S. da. et al. Elementos em Análise Textual Discursiva (ATD) na identificação de um Tema Gerador para o ensino de Química na Educação Básica. Revista Interdisciplinar de Ensino, Pesquisa e Extensão, Cruz Alta, v.5, n.1, p.1-16, 2017.

SILVA, A. F. G. da. A construção do currículo na perspectiva popular crítica: das falas significativas às práticas contextualizadas. 2004. Tese (Doutorado em Educação: Currículo) Faculdade de Educação, Pontifícia Universidade Católica de São Paulo, São Paulo, 2004.

SOUSA, P. S. de. et al. Investigação Temática no Contexto do Ensino de Ciências: Relações entre a Abordagem Temática Freireana e a Práxis Curricular via Tema Gerador. Alexandria: Revista de Educação em Ciência e Tecnologia, Florianópolis, v. 7, n.2, p. 155-177, nov. 2014.

SOUSA, R. S. de.; GALIAZZI, M. do C. A categoria na Análise Textual Discursiva: sobre método e sistema em direção à abertura interpretativa. Revista Pesquisa Qualitativa, São Paulo, v.5, n.9, p. 514-538, dez. 2017. 
SOUSA, R. S. de.; GALIAZZI, M. do C. Compreensões acerca da Hermenêutica na Análise Textual Discursiva: marcas teórico-metodológicas à investigação. Contexto \& Educação, Ijuí, v. 31, n. 100, p. 33-55, set./dez. 2016.

SOUSA, R. S. de.; GALIAZZI, M. do C.; SCHMIDT, E. B. Interpretações fenomenológicas e hermenêuticas a partir da Análise Textual Discursiva: a compreensão em pesquisas na Educação em Ciências. Revista Pesquisa Qualitativa, São Paulo, v. 4, n. 6, p. 311-333, dez. 2016.

STUANI, G. M. Abordagem Temática Freireana: uma concepção de formação permanente dos professores de Ciências. 2016. Tese (Doutorado em Educação Científica e Tecnológica), Centro de Ciências da Educação, Universidade Federal de Santa Catarina/UFSC, Florianópolis, 2016.

TORRES, J. R. et al. Ressignificação curricular: contribuições da Investigação Temática e da Análise Textual Discursiva. Revista Brasileira de Pesquisa em Ensino de Ciências, Belo Horizonte, v. 8, n.2, maio/ago. 2008.

WATANABE, G. (org.) Educação Científica Freireana na Escola. São Paulo: Editora Livraria da Física, 2019.

Recebido em: 31 de outubro de 2020.

Aceito em: 21 de novembro de 2020. 